\title{
TYPES OF BORROWINGS IN TAGALOG/FILIPINO
}

(with Special Remarks on the Ortograpiyang Pambansa, 2013)

\author{
Ekaterina Baklanova \\ Lomonosov Moscow State University, Russia \\ Institute of Asian and African Studies \\ baklanova@gmail.com
}

\begin{abstract}
Modern Tagalog, or Filipino as the National Language, is widely famous for its high ability to adopt lexical units from various languages in contact. Through the ages it has assimilated a vast amount of borrowings, primarily from Malay, Sanskrit, Chinese, Arab and later, Spanish and English.

Many linguists have contributed so far to the investigation of the borrowings in Tagalog, such as Philippine scholars G. Chan Yap, J.Francisco, A. Gonzalez, R.M. Goulet, C. Lopez, E.A. Manuel, F. Otanes, J. Panganiban, as well as Western linguists K.A. Adelaar, F. Blake, M. Haspelmath, H. Kelz, H. Kern, J.-P. Potet, P. Steinkruger, P. Schachter, T. Stolz, R. Thompson, J. Wolff, D. Zorc, K. Zuraw, and Russian Philippinists V. Makarenko, L. Shkarban, Yu. Studenichnik, and so on. However, there have been lacunas in the overall research: the focus of many works has been set on the phonetic assimilation of the Spanish and English loans, with scarce data on the morphology and semantics, especially of the Asian lexemes. The phenomenon of the borrowings interfering with the recipient system is understudied. A uniform classification of the various borrowed elements is also needed. (I attempted to fill some of the gaps in Baklanova 2004; 2006; 2009).

This paper presents a typological classification of borrowings in Tagalog, while the phenomenon of the borrowings interfering with the recipient system will also be considered. Some remarks will be made on the Filipino State Orthography (Ortograpiyang Pambansa 2013) regarding the introduction of foreign letters to the alphabet, and the problem of false cognates in modern Tagalog/Filipino.
\end{abstract}

\section{Keywords}

Assimilation, classification of borrowings, interference, language contact, loanword 


\section{About the Author}

Ekaterina Baklanova studied at the IAAS of the Lomonosov Moscow State University (MA in 2003). In 2009, she defended her PhD Thesis "Lexical Borrowings in the Tagalog Language and the Problem of Interference" (in Russian). She also worked as English-Filipino interpreter at the Philippine Embassy in Moscow (2003-2005). Currently, she conducts research on Philippine philology and has taught Filipino and History of the Philippine literature since 2002. She has participated in international conferences including the 7th ICAL (Netherlands, 2004), 1oth ICAL (Philippines, 2006) and Taboan Writers Festival (Philippines, 2014). She has about 25 publications on the Tagalog linguistics (language contact) and Philippine literature.

\section{Abbreviations Used}

$\begin{array}{ll}\text { Ar } & \text { Arab } \\ \text { Eng } & \text { English } \\ \text { Hok } & \text { Hokkien Chinese } \\ \text { Kpm } & \text { Kapampangan } \\ \text { Mal } & \text { Malay } \\ \text { M-W } & \text { Monnier-Williams (see Monnier-Williams 1899) } \\ \text { PAN } & \text { Proto-Austronesian } \\ \text { PMP } & \text { Proto-Malayo-Polynesian } \\ \text { Skt } & \text { Sanskrit } \\ \text { Sp } & \text { Spanish } \\ \text { Tag } & \text { Tagalog } \\ & \\ \text { coll } & \text { colloquial (word) } \\ \text { fem. } & \text { feminine (gender) } \\ \text { masc. } & \text { masculine (gender) } \\ \text { suf. } & \text { suffix: }\end{array}$

act. suf. - actor suffix; diminut. suf - diminutive suffix; internat. suf. - international suffix; gerund. suf. - gerundial suffix. 
In spite of much attention paid to the borrowings in Tagalog, ${ }^{1}$ there are only a few extensive works on its different aspects. Thus, considerable contributions to the research of the Chinese loanwords have been made by Cecilio Lopez (1944), E. Arsenio Manuel (1948), G. Chan Yap (1973; 1974). The Malay loanwords in Tagalog (incl. some Arab and probable Tamil lexica adopted via Malay) were the subject of papers by J. Francisco (1965), J. Wolff (1976), D. Zorc (1993), V. Makarenko (1992) and a recent extensive work by J.-P. Potet (2013). The borrowings from Kapampangan were studied by Zorc (1993) and A. Gonzalez (2005).The research on Sanskrit loanwords (including those penetrated via Malay and Javanese) were undertaken by H. Kern (188o), F. Blake (1918), J. Gonda (1952), J. Francisco (1973, 1985), and others. More works have been dedicated to various aspects of the Spanish and/or English lexica in Tagalog as the most recent and the largest layers of the borrowings in the recipient. The assimilation of the Spanish lexemes in Tagalog was studied by C. Lopez (1944, 1973), J. Panganiban (1961), T. Alcántara (1999), J. Wolff (1973; 2001), E. Baklanova (2006), J.-P. Potet (2016), and others. The lexical borrowing from English was investigated by R.M. Goulet (1971), D. Zorc (1990), H. Kelz (2000), Yu. Studenichnik (2011) and many more, while the aspects of interference have received attention from R. Goulet (1971), K. Zuraw (1996), T. Stolz (e.g. 2012), E. Baklanova (2004; 2016).

The intensive and continuous contact of Tagalog with the above languages, as well as the prestige of some donors has led to an active adoption of their lexica. Thus, not only cultural borrowings, but also core borrowings (in Myers-Scotton's terms [239]) are abundant in Tagalog. The table below shows that even for some core semantics listed among the least borrowable in the Loanword Typology Project (LWT) [Haspelmath and Tadmor, World Loanword Database], Tagalog has loanwords, some of which have fully or partly supplanted the corresponding native words. Among the lexical meanings with less than $0.1 \%$ of borrowability (as per LWT), quite a number of borrowings can be found in Tagalog, for example:

TABLE 2. LOANWORDS WITH LESS THAN 0.1\% BORROWABILITY IN TAGALOG

\begin{tabular}{|l|l|l|}
\hline Tagalog lexeme & Donor lexeme & $\begin{array}{l}\text { Borrowability } \\
\text { (as per LWT, \%) }\end{array}$ \\
\hline kánan “right (side)" & $\begin{array}{l}\text { Mal./kanan/(<"ka-wanan) [Wolff } \\
1976]\end{array}$ & 0.04 \\
\hline áte 'elder sister' & $\begin{array}{l}\text { Hok./a+ci/'appeal form to elder } \\
\text { sister' [Yap] }\end{array}$ & 0.06 \\
\hline kúya 'elder brother' & $\begin{array}{l}\text { Hok./ko+a/appeal form to elder } \\
\text { brother' [Yap] }\end{array}$ & 0.06 \\
\hline
\end{tabular}




\begin{tabular}{|c|c|c|}
\hline ditse 'second elder sister' & $\begin{array}{l}\text { Hok./di+ci/appeal form to the sec- } \\
\text { ond elder sister' [Yap] }\end{array}$ & 0.06 \\
\hline $\begin{array}{l}\text { /bunsóq/'the youngest child' } \\
\text { (cf. PMP / "udehi/last, late;the } \\
\text { youngest child, Tag huli 'last, } \\
\text { late') }\end{array}$ & $\begin{array}{l}\text { Mal./bónsu///búnsu/the youngest } \\
\text { child' [Blust and Trussel] }\end{array}$ & 0.06 \\
\hline $\begin{array}{l}\text { kantá 'song (partly supplanting } \\
\text { Tag áwit 'song, hymn') }\end{array}$ & Sp. cantar 'to sing' & 0.06 \\
\hline $\begin{array}{l}\text { alám 'known' } \\
\text { (cf. PAN /"bajaq/known, com- } \\
\text { prehended, Tag batíd 'known, } \\
\text { comprehended') }\end{array}$ & Ar. /aleilm/'knowledge; science' & 0.07 \\
\hline $\begin{array}{l}\text { lábi ‘lip' } \\
\text { (cf. PAN /"biRbiR/ 'lip', PMP } \\
\text { /"bibiR/'lower lip' [Blust and } \\
\text { Trussel]; Tag bibíg 'mouth') }\end{array}$ & ? Jav. lambe 'lip', or Sp. labio 'lip’ & 0.08 \\
\hline $\begin{array}{l}\text { úsap ‘talk, conversation' } \\
\text { (cf. PMP baqbaq 'speak; say') }\end{array}$ & $\begin{array}{l}\text { Mal. /účap/utterance (esp. emotion- } \\
\text { al)' [Blust and Trussel] }\end{array}$ & 0.09 \\
\hline pandáy 'smith' & $\begin{array}{l}\text { Mal. pandei 'expert; craftsman' <Skt. } \\
\text { Ipanditita/wise; scientist; philoso- } \\
\text { pher' [M-W: 580], or / pāndya/ "wise, } \\
\text { learned" [Adelaar] }\end{array}$ & 0.09 \\
\hline $\begin{array}{l}\text { bráso 'arm' } \\
\text { (cf. PMP *baRa 'arm/hand', Mal. } \\
\text { leyan 'arm') }\end{array}$ & Sp. brazo 'arm' & 0.09 \\
\hline
\end{tabular}

Some borrowings have even supplemented the Tagalog set of function words, ${ }^{2}$ e.g.: Sanskritisms úpang "for, so as to" [< Skt /upa/ 'to; towards; with' (M-W: 194) + attribution particle], samantála "meanwhile" [< Skt samanantara 'immediately following; closely related' (M-W: 1154)]; Hispanisms bastá "with the proviso that; just, only" [< basta (que) "is enough (so that)"], ni "neither", o "or", pára "for, so that", péro "but, however", pórke [< Sp pórque] "because" (for more Spanish loans see Wolff 1973).The Spanish más "more" has been added to the inventory of Tagalog comparative adjectives: Tag magandá "beautiful" - magandá pa /lalong magandá /mas magandá "more beautiful." I have to disagree with Patrick Steinkrüger's assumption that "none of the numerous discourse particles in Tagalog are of Spanish origin" (213). According to my data, the following Spanish borrowings are used as discourse markers in Tagalog:

- as response: sige "okay, agreed, right; Go ahead!” [< Sp ¡Sigue! 'Go ahead!, seguir 'to follow'];

- organizing the discourse: bweno "so, well / well then" [< Sp bueno 'good, nice; okay, alright'] (the word is getting obsolete and tends to be replaced by the English "so" $)$; 
- as hedges (to sound less direct): medyo "somewhat, comparatively, a little, rather" [<Sp medio 'half; average; medium, etc.'], parang "looks like / it seems; apparently; somewhat" [< Sp para "for, towards" + Tag attribution particle $n g$ ], siguro "maybe, probably" [< Sp seguro 'sure, assured; safe; definitely, etc.'];

- ordering one's statements: Una /Uno,... "Firstly / First of all..." [< Sp uno / una 'first (masc./fem.)'];

- showing attitude, interjections: Grabe!"How sad!", "How serious / severe!" [< Sp grave 'serious, severe, etc']; syempre "of course, sure" $[<$ Sp siempre 'always']; Sus! / Susmariosep! “Jesus!”, “Good Lord!” [< Sp jJesús, María y Joseph! 'Bless you'].

The analysis of the different layers of borrowings in Tagalog allows them to be categorized into types based on well-known principles by Einar Haugen. The nomination of a concept borrowed from one language into another is usually realized through a) the borrowing of the corresponding word, or b) the creation of its equivalent in the recipient language by translation, invention of a new word (neologism) for the borrowed concept, or extension of the semantics of a native word to acquire the new meaning.

In Haugen's terminology borrowed items are divided into "loanwords" (both form and semantics are copied), "loanblends" (words consisting of a copied and a native part), and "loanshifts" (only semantics is copied). "Loanshifts" fall into the subgroups of "loan translations" (calques) and "semantic borrowings" (only semantics is copied and added to an already existing word in the recipient). However, such classification does not allow delimitating loanwords and nonce borrowings. Thus, according to the Encyclopedia of Language and Linguistics, "nonce borrowings are, unlike loanwords, not adapted phonologically. But they are, unlike code switches, morphologically and syntactically integrated into the host language" (Mahootian 514). It also appears of importance to distinguish lexical borrowing (a lexeme with its form and semantics adopted) from a semantic one (foreign semantics are copied and added to a word of the recipient). In this view the term "semantic borrowings" could be used to cover both "loanshifts" and "loan translations," as opposed to the lexical borrowing.

Basing on the above, I suggested to divide all borrowings in Tagalog into the following groups and subgroups (Leksicheskiye Zaimstvovaniya):

I. Lexical Borrowings

1.1. Complete borrowings

a) unassimilated (nonce borrowings)

b) assimilated (loanwords)

1.2. Mixed borrowings

Kritika Kultura 28 (2017): -054

(C) Ateneo de Manila University

<http://journals.ateneo.edu/ojs/kk/> 
a) with native elements

b) without native elements

II. Semantic Borrowings

2.1. Extensions

a) semantic extensions

b) phonetic extensions

2.2. Creations

a) calques

b) neologisms

III. Hybrid Neologisms

3.1. Lexical hybrids

3.2. Grammatical hybrids.

\section{LEXICAL BORROWINGS}

A lexical borrowing, in contrast to a semantic one, implies that both the meaning and the morphemes of a foreign word are acquired by Tagalog as a recipient language. This class of borrowings will then include complete and mixed borrowed words.

1.1. Complete borrowings are the foreign lexemes adopted by Tagalog wholly.

a) Nonce borrowings as unassimilated lexemesretain to a considerable degree their phonetic, ${ }^{4}$ semantic and graphic appearance. In Tagalog this group is mostly represented by the recent borrowings from English, which are abundant in the modern Tagalog, or Filipino, especially in the everyday speech of educated Filipinos and in media, politics, economics and science. Due to the widespread bilingualism in the country, code-switching has become a lingua franca of urban areas throughout the Philippine Archipelago (Bautista). These daily practices of code-switching, especially intrasentential (switches within a clause involving a phrase, a single word or across morpheme boundaries) provide a vast amount of new English words. Those used more often are gradually getting borrowed by Filipino monolinguals, too, thus becoming a part of the Tagalog vocabulary. The English nonce borrowings can be found in any type of the Filipino speech, from everyday talk to a specific report:

- Kina-shock ko talaga yun. - "That really shocked me";

- Nagtungo sila sa Iloilo City at doon sila na-stranded. - "They headed to Iloilo City and there they got stranded"; 
- eskuwelahang stay-in "a boarding school";

- full time na guro"a full time teacher";

- "23\% $n g$ carbon dioxide emissions ay galing sa mga motor vehicles na nagpapalala naman sa polusyon sa hangin at climate change" (The Philippine Star, 18 Feb. 2014).

The above examples demonstrate that nonce borrowings become embedded into the Tagalog morphological system - that is, may act as roots taking over the Tagalog prefixes, and are handled in accordance with the norms of the Tagalog conjugation. When reduplication is needed (for a Future or Present Tense form), the reduplicated part of a borrowed word's first syllable usually becomes assimilated, while the whole borrowed root remains unassimilated. Nonetheless Tagalog speakers often handle them as foreign words, either italicizing them in the text, or putting a hyphen between the unassimilated "root" and the Tagalog prefix used with it:

- regular na pagmi-maintain ng bus - "regular maintenance of the bus";

- Mahirap ang pagdodraw-up ng project - "Drawing up a project is difficult."

However, due to the intensive flow of English nonce borrowings into Tagalog in the last decades, there are traces of the tendency to retain the original phonetics of a donor word when reduplicated, as in: macoclose "will be closed", magvovolunteer "will [become a] volunteer," and many others.

b) Assimilated borrowings, also called loanwords in the strict use of the term (Mahootian 513) are those adjusted to Tagalog norms and needs through assimilation at all the levels-phonological, morphological and semantic. ${ }^{5}$ Phonetic assimilation implies that the phonemes of a foreign word are substituted with the corresponding Tagalog phonemes or sound combinations; a consonant or vowel is dropped or inserted to avoid a cluster; other changes may occur to adjust the sound structure of a borrowing to the Tagalog norms, such as:

- Hok/lūn-piã/ "a sweet soya pie" > Tag lumpiyâ"a spring roll,"

- Skt/hridaya/"a heart; a soul"> Tag haraya"imagination,"

- Sp ladrillo > Tag laryo "a brick",

- Eng dimple > Tag dimpol. 
Morphological assimilation implies that borrowed words and word combinations are simplified into indivisible roots or root words, then are used for a further derivation according to the Tagalog rules:

- Skt /hina/ "weaker/lower than; abandoned; deficient, etc" > Tag hinà, kahinaan "weakness, fragility, feebleness, lack of efficacy, etc." mahinà "weak, frail; weakly, poorly, etc."

- Ar /hikay'at/ "preach, legend" > Tag hikayát "persuasion," hikayatin "to persuade, to talk into,"

- Mal barat laut "North-West" > Tag balaklaot "north-western wind,"

- Sp en vez (de) "instead (of)" > Tag imbes "instead (of),"

- Eng (to) stand by > Tag istambáy "idler, lazy; unemployed," istambáyan "a place where idlers gather," istambayán "to philander."

Some loanwords have undergone a hyper-correction in Tagalog, meaning their morphemic structures have been misinterpreted by Tagalog speakers. Thus, a Malay borrowing of Pontianak "spirit of a deceased pregnant woman" has become patianák in Tagalog, and then the first syllable $p a$-might have been mistaken for the Tagalog prefix $p a-$-, so it had been dropped, with tianák left as a root word for "evil spirit." Moreover, even in dictionaries one may find such examples of the wrong interpretation-for example, the borrowing paligsá "test, quiz" (from Sanskrit parìkşā "investigation, examination, check-up") was given as a derivation from the "root ligsá" (English 1986-2002; Rubino).

A borrowed word also undergoes a semantic assimilation; the meanings of borrowings get adjusted to the semantic lacunas existing in the recipient language - thus, a meaning or a group of meanings may be narrowed or extended; may undergo metaphoric, metonymic or other changes, e.g.:

- Hok /oan/ "insect" > Tag uang "beetle, coconut beetle,"

- Skt /gunita/ "multipled; used often" > Tag gunitâ "memory," magunitâ "to recall,"

- Sp todo "whole" > Tag todo "whole; a full exhaustion; dead,"

- Eng (to) believe > Tag bilib "very impressed."

1.2. Mixed borrowings (loanblends, in E. Haugen's taxonomy) are those borrowed into a language with their partial replacement with some native elements of the recipient. In the case of Tagalog, borrowed morphemes may be substituted with those of previously assimilated foreign lexica. Thus Tagalog mixed borrowings may contain some native elements, or may consist only of borrowed material, such as: 
a) with native elements:

- Sp carnero marino "seal" (lit. "ram-sea") + Tag dagat "sea" > karnerongdagat "seal,"

- Mex-Sp (naran)jita "small tangerine or grapefruit" + Tag dalan(dán) "orange" > dalanghita "tangerine";

b) without native elements:

- Sp (porta)monedas "a purse" + Tag kwarta "money" [Sp cuarto] > kwarta moneda "a purse,"

- Sp largo (mira) "binoculars, telescope" + Tag bista "sight; view, landscape" [< Sp vista] > larga bista "binoculars, telescope" (while Spanish vista larga means "long-sight(ed)").

Such recent partially native borrowings seem to be relatively scarce. There are much more hybrid neologisms in the modern Tagalog, or the new words invented by Filipinos with the use of some native and already assimilated borrowed material (see below).

\section{SEMANTIC BORROWINGS}

Semantic borrowings (or loan shifts, as per E. Haugen) emerge when only the concept, the meaning of a foreign word is adopted, while all its morphemes are substituted with the native morphemes of the recipient language. Thus the borrowing is limited to the shift in the usage of either a native word (and then its meaning gets extended) or a combination of native morphemes (and then a neologism is created). In the case of Tagalog, both its native words and previously assimilated lexemes may acquire new borrowed semantics.

2.1. Extensions in Tagalog are the result of transportation of a borrowed meaning or a circle of meanings onto an already existing Tagalog lexeme of similar semantic or phonetic appearance, for example:

a) semantic extensions:

- Tag Kalihim, or sekretaryo [<Sp secretario "confidant, attorney; assistant"]) "attorney, secretary as an assistant in work" + "Minister" [< Eng secretary]; 
In many cases such semantic extension is provoked by false cognates, which Virgilio Almario calls "salitang siyokoy" (Ortograpiya 20). However, the existence of false cognates in Tagalog is not the result of some ignorance, but the case of an almost inevitable interference (or influence) of English on the corresponding borrowed words, mainly of Spanish origin, in the minds of Filipino bilinguals:

- Tag actual / aktwál [< Spanish actual] "current, present; timely" + "real" [< Eng actual] (cf. Sp real for "real," verdadero for "true"),

- direksyón [< Sp dirección] "direction, course; address; administration" + "directive, instruction, precept, command" [<Eng direction] (cf. Sp directriz, directive for "directive").

b) Phonetic extensions are a result of transportation of a borrowed meaning onto a native word with similar phonetic appearance:

- Tag tipon "collecting, gathering" + "type" [<Sp tipo "a type"];

- Tag kámbas "canvas" [< Eng canvas] + "check-up, investigation" [<Eng to canvass];

- Tag asusena [<Sp azucena] "white lily" + coll. play-on-words "cooked $\operatorname{dog}^{\prime}$ [< Tag aso "dog" and Sp cena "supper, evening meal"].

2.2. Creations are new combinations made of the lexemes already existing in the recipient language (both native and previously borrowed), to assimilate new borrowed semantics.

a) Calques are a kind of new words created by transferring a foreign lexeme's meaning, as well as its morphological structure onto the semantically corresponding lexical unit(s) of the recipient. Here Tagalog largely uses previously assimilated borrowings, too:

- Tag agham-panlipunan / agham lipunan (lit. "science-for-society" / "science-society") < Eng social science,

- Tag doble-talim (<Sp doble "double") lit. "double-edge" <Eng double-edged,

- Tag tumakbo sa termino (<Sp termino "a term") lit. "run for term" < Eng to run for a term.

b) Neologisms are new words invented by Tagalog speakers to acquire some concepts from foreign words. They may not have any formal or structural analogies with the originals, thus only the meaning is "borrowed." Such neologisms are rather scarce in the modern Tagalog, some of them have 
been specially invented within the framework of the bygone language purification, the others have emerged spontaneously as an attempt to give names to foreign concepts:

- Kapulungan (lit. "place-where-gather") "an assembly; a meeting" < Sp Cámara, Eng Chamber/assembly (e.g. Mababang Kapulungan "Lower Chamber"),

- pader-ilog (lit. "wall-[<Sp pader] - river") "embankment" < Sp malecón,

- talatinigan, talahulugan (lit. "list-sounds," "list-meanings") "a dictionary" < Sp diccionario, Eng dictionary.

\section{HYBRID NEOLOGISMS}

This is a completely different type of borrowing, caused by morphological interference. There is no transfer of either a lexeme or its meaning, but a creation by the recipient language of new words using both native morphemes and foreign elements (lexical or even grammatical), singled out of previously assimilated borrowings. Again, in the case of Tagalog, hybrid neologisms are often created of parts of assimilated borrowings only, with no native units added. They may be $a$ result of the hypercorrection (or wrong interpretation) of an already assimilated loanword, or an attempt to create a word with some new meaning. Thus, we may divide hybrid neologisms into:

3.1 Lexical hybrids are neologisms created with the use of foreign lexical morphemes (roots), or their parts singled out of previously assimilated loanwords. Thus, an old Malay lexeme jurubahasa (lit. "expert - language") "interpreter" has become dalubhasà in Tagalog "expert; connoisseur (in general)." It appears to have been wrongly divided into "quasi-morphemes" dalub + hasà, which was probably evoked by the similarity of its second part with the Tagalog word hasà "whetting; sharp." As a result of this misinterpretation the native hasà has acquired a "figurative" meaning "training, expert check", and the "new morpheme" dalub-is sometimes taken as "prefix denoting expertise." In this new status dalub- has even become part of such hybrids as dalub-aghám "a scientist" (with Tag aghám "science" < Skt āgama "sacred science, religion"), dalub-wikà "a linguist" (Tag wikà "language, speech").

Filipinos are famous for their ingenuity and bright humor in creating new words and expressions in their colloquial speech, such as: 
- kontrabida "leading negative personage (in a movie)" < kontra "against, anti-" $[<$ Sp contra $]+$ bida "leading personnage (in a movie)" $[<$ Sp vida "a life, a lifestyle, a story"],

- biyahilo "travel sickness" < biyahe "travel" [< Sp viaje] + hilo "dizziness; vertigo" [< Sp giro "rotation; turn, spin"],

- salamuch "thanks a lot" < salamat "thanks" + much $[<$ Eng]

- taralets "let's go" < Tara (na)! "let's go" + let's [< Eng].

The Philippine slangs are abundant with hybrids created as plays on words (see Zorc and San Miguel).

3.2. Grammatical hybrids are created with the use of borrowed grammatical morphemes in order to impart their grammatical meanings to existing Tagalog words. This is one of the brightest examples of interference, when the many Spanish and English words assimilated by Tagalog start to influence the Tagalog language system. Thus, quite a number of the borrowed grammatical morphemes are now used as partly productive units for the Tagalog wordbuilding, e.g.:

- kaskás "a jerk, spurt, gallope" - kaskasero "a speed maniac" [+ Sp actor suf. -ero],

- sabong "a cock fight" - sabungero "addicted to cock fights,"

- amin "our; (to) admit; to proclaim as one's property" - aminado "admitted (one's guilt)" [+ Sp pret. suf. -ado/ido],

- aguha [ < Sp aguja "a needle"] - aguhílya "a hairpin" [ + Sp diminut. suf. -illa];

- dalaga "a girl, a maiden" - dalagita "a very young girl" [+ Sp diminut. suf. -(u)ita]

- sakbát "sling, put over a shoulder" - de-sakbát"slinging over a shoulder" [+Sp prep. de, in Tag seems to have acquired the meaning "having the mentioned object/quality"],

- salamín "glass, mirror, spectacles, cristal" - de-salamín "wearing spectacles,"

- sanaysáy "an essay, a story" - sanaysayísta [+ Sp prof. suf. -ista] "an essayist, writer of articles,"

- bays [< Eng buys] "a buy" > baysing [+ Eng gerund. suf. -ing] "shopping,"

- panuelo [< Sp pañuelo "a (hand)kerchief, scarf"] > panueloles [+ Eng suf. -less "without"] "without a kerchief, barely-headed."

The use of borrowed affixes as productive indicates a significant shift in the Tagalog language structure, even in grammar. A huge number of Spanish loans containing affixes with gender markers has determined the emergence 
of gender agreement cases, thus establishing a marginal gender in Tagalog (term by Stolz 101), for example:

- bulakbulero/-a, from the anglicism bulakbol "vagabond, idle, truant; black ball (in ballot)" [< Eng black ball],

- lasenggo/-a "drunkard (masc/fem)" < Tag lasing "drunk,"

- problemado/-a "having a problem (masc/fem)" < Sp problema or Eng problem.

- "Concerned lang ako sa anak mo [na dalaga] kasi bulakbolera" "I'm just concerned about your child [girl], cause [she's] a truant [fem]" (The Philippine Star, 21 June 2010); but "Kung nagko-computer games ang boss sa opisina 'it's okay.' Kung empleyado, 'bulakbolero." "If the boss in the office plays computer games, 'it's ok'. If an employee, 'truant[masc]" (The Philippine Star, 17 Jan. 2003);

- "Problemado sa Misis, Tumalon sa Dagat" "Having-problems [masc] with wife, jumped to the sea" (Abante, 11 Feb. 2016); "Problemada ang isang magandang aktres sa pera" "A certain actress has-problems [fem] with money" (Abante, 25 Nov. 2012). (qtd. in Baklanova, "On Marginal Gender" 30-31)

As assumed by Baklanova ("On Marginal Gender"), the use of gender in Tagalog/Filipino may expand via: a) word-building with partly productive borrowed Spanish affixes; b) hispanization of English lexica in the process of its borrowing (see below).

The borrowed lexica have also interfered with the Tagalog language system on other levels, including the phonology. The original Tagalog alphabet is known to have neither $/ f /$, nor $/ v /$ or even such phonological opposition as $/ o /-/ u /$ (as they were previously allophones). But now, having assimilated a large number of Spanish and English borrowings containing these phonemes, Filipinos started to use them in their speech(see e.g. Baklanova 2004). And this is actually one of the reasons why the new Ortograpiyang Pambansa (2013) contains new letters. However, not all of them appear equally important for the alphabet. Thus, the letters $F, J, V, Z$, according to point 4.1. of the Ortograpiya, reflect the phonemes of other Philippine languages, like Ifugaw, Ivatan and others (17). Letters $Q$ and $X$ are a part of many borrowed words, especially onomastic, so the authors think it important to add them to the Filipino alphabet. However, the other 2 borrowed letters $-C$ and $\tilde{N}-$ do not seem necessary at all. So we turn to the Ortograpiya for an explanation. It runs:"<...> In the case of $\mathrm{C}$, the problem is that it may be pronounced in two ways, as it may represent either $\mathrm{K}$ or $\mathrm{S}$. For example, it's sound is $\mathrm{K}$ in the 
case of the first letter in coche (kotse), but it is S as the first letter of ciudad (siyudad)" (Ortograpiya 18, translation mine).

This seems a rather doubtful argument, as the cited coche and ciudad are two original Spanish words, and as such they do not pertain to the Philippine languages. It is only their borrowed variants kotse, siyudad, that have long ago become a part of Tagalog, and now of Filipino. So $K$ does represent correctly the initial sound in the borrowed word kotse. As for siyudad, in Tagalog or Filipino it is pronounced only with the initial /s/, and never with the interdental $/ \theta /$ that is actually represented by the Spanish initial in ciudad. So one can see that there is no need to search for a representation of $c$ as it is a Spanish letter, not pertaining to the Filipino or Tagalog vocabulary.

As for the letter $\tilde{\mathrm{N}}$, the authors of the Ortograpiya admit in point 4.5., that "even in Spanish the words containing N are very limited" (Ortograpiya 18, translation mine). As for the modern Tagalog or Filipino, there are probably less than a dozen of such words. And, as the Ortograpiya runs correctly, "several words that have already entered Filipino contain NY" (Ortograpiya 18, translation mine), which stand for $\tilde{N}$ in the Spanish originals. So, the question arises, is there a real need to introduce a new foreign letter $(\tilde{\mathrm{N}})$ into the Filipino alphabet for a handful of old borrowings, which are already successfully used with the sound combination (NY)?

There is another noteworthy effect of the phonological interference in modern Tagalog / Filipino, which is the influence of Spanish and English borrowed cognates on each other. There are quite a number of Spanish and English cognates in the modern Tagalog. Within the process of interference the newly borrowed English words start to influence and modify the phonetics of their analogies borrowed from Spanish. Or vice versa, under the influence of the previously adopted Spanish loans their newly borrowed English cognates are modified, "hispanized" in phonetics. Thus,

a) "anglicization"of the Spanish borrowings:

- Sp biología > Tag biolohiya /bayolohiya - under the influence of Eng biology (-/ai/-),

- Sp estructura > Tag istruktura /istraktura - due to Engstructure (-/ $/ /-)$,

- Spreceta $>$ Tag reseta / resít "a prescription; a receipt"- due to Eng receipt (-/í:t/-),

- Spcontemporáneo > Tagkontemporanyo "contemporary,"kontemporaryo - due to Eng contemporary; 
b) "hispanization" of the English borrowings:

- Eng atheist $>$ Tag ateista - with the Spanish suffix - a (but the Spanish for "atheist" is ateo),

- Eng incentive > Tag insentibo (cf. Sp iniciativa"incentive"),

- Eng materialistic> Tag materialistiko (cf. Sp materialista "materialistic"),

- Eng majority for "the biggest quantity; adulthood"> Tag mayoridád "the biggest quantity" (cf. Sp mayoría "the biggest quantity", mayoridad "coming of age").

In Ortograpiya such false cognates are called "salitang siyokoy" (Ortograpiya 20), and I emphasize that their creation is not a matter of ignorance of Spanish, as the Ortograpiya regards it, but rather a result of this process of interference in Tagalog /Filipino, when borrowed words start to influence each other, and the language itself. There is also an example in the Ortograpiya that I wish to single out: "... It has been noticed when Rod Navarro in his radio program used "konsernado," thus hispanizing the English word "concerned"... The correct form for the Spanish word is "konsernido" (concernido)" (20, translation mine).

In defense of the Filipino reporter, it is not his lack of knowledge that induced the creation of konsernado, but the above-mentioned tendency of Tagalog / Filipino to use borrowed suffixes to form a new word with a desired meaning. So, I would rather call konsernado a hybrid neologism created like the word aminado "admitted", with the addition of the Spanish suffix -ado to acquire the desired English semantics "worried/interested about something; taken into account; related". It should be noted, that the Spanish concernido mentioned in the Ortograpiya is not much used in Spanish to mean "concerned; busy / interested in something, worried about something"; rather it is the word preocupado.

\section{SUMMARY}

The large-scale borrowing of various types by Filipinos in different historical periods, toppled with the adoption of borrowed grammatical morphemes for the native word formation and the extension of grammatical and phonetic inventory of the modern Tagalog/Filipino, demonstrate how permeable the recipient language has become for foreign influences. The process of interference by the donor lexica into the Tagalog/Filipino language system has already started and is aggravated by 
the Filipino bilinguals' daily practice of code-switching. So, it appears important for the language policy authorities to somehow canalize this process, in order to help the Filipino language develop and extend, but without overloading it with unnecessary foreign or newly created language units. 


\section{Notes}

1. I adhere to the position that "the terms 'Pilipino,' 'Filipino,' or 'Tagalog' all refer to one and the same language" (Wolff 2006: 472). Thus in the present paper I shall use the term "Tagalog language" to refer to any stage of this language's development, including its current status as the Philippine National language (Filipino). The paper is based on the research results presented in my $\mathrm{PhD}$ Thesis (synopsis published in Russian: Baklanova, Leksicheskiye Zaimstvovaniya v Tagalskom Yazyke I Problema Interferencii).

2. Let alone the numerals and quantity words borrowed from Spanish and English (see Goulet), and some of Sanskrit (Baklanova, "Interference in Tagalog" 104).

3. Yu. Studenichnik in his PhD Thesis (in Russian) assumes that the English particle so has already become a loanword in Tagalog (Studenichnik 2006: 87).

4. Phonetic substitution will obviously take place, for speakers of the recipient language will inevitably perceive and reproduce borrowed words with the recipient's phonetic inventory.

5. There is also quite a number of Spanish phonetically assimilated onomastic lexemes, which retain the original graphics (e.g. Aquino, Rizal, Davao, Peñafrancia, etc).

6. This is how Carl Rubino calls it in his Dictionary (52). See also English 403. 


\section{Works Cited}

Abante, www.abante.com.ph. Accessed 11 Feb. 2016.

Adelaar, K. "Malay and Javanese Loanwords in Malagasy, Tagalog and Siraya (Formosa)."

Bijdragen tot de Taal-, Land-en Volkenkunde, vol. 150, no. 1, 1994, pp. 50-65.

Alcántara y Antonio, Teresita. Mga Hispanismo sa Filipino (Batay sa Komunikasyong

Pangmadla ng Filipinas: Pag-aaral Lingguwistiko). Sentro ng Wikang Filipino, U of the Philippines Diliman, 1999.

Baklanova, Ekaterina. "Interference in Tagalog as a Result of Borrowing." Pilipinas: A Journal of Philippine Studies, no. 42, 2004, pp. 95-116.

--. "Morphological Assimilation of Borrowings in Tagalog." Tenth International Conference on Austronesian Linguistics, 17-20 Jan. 2006, Puerto Princesa City, Philippines, www-01.sil.org/asia/Philippines/ical/papers.html. Accessed 1o Dec. 2016.

-.. Leksicheskiye Zaimstvovaniya v Tagalskom Yazyke I Problema Interferencii [Lexical Borrowings in Tagalog and the Problem of Interference]. PhD Thesis, IAAS of Lomonosov Moscow State University, 2009.

--. "On marginal gender in Tagalog: A case study." Proceedings on the XII International Conference: Languages of the Far East, South East Asia and Western Africa, 16-17 Nov. 2016, LESEWA, Moscow, [Yazyki Narodov Mira], 2016, pp. 25-33.

Bautista, M.L.S. “Tagalog-English code-switching as a mode of discourse."Asia Pacific Education Review, vol. 5, no. 2, 2004, pp. 226-233.

Blake, Frank R. "Sanskrit Loan-words in Tagalog."John Hopkins University Circulars, vol. 22, no. 163, June 1918, pp. 63-65.

Blust, Robert and Stephen Trussel. Austronesian Comparative Dictionary (ACD), www. trussel2.com/acd/. 1995. Accessed 10 Dec. 2016.

Chan Yap, Gloria. "Sound Changes in Tagalog Words of Chinese Origin." Philippine Journal of Linguistics, vol. 4-5, no. 1-2, 1973, pp. 48-55.

--. Hokkien Chinese borrowings in Tagalog. Department of Linguistics, School of Pacific Studies, Australian National U., 1980.

Collins Complete and Unabridged Spanish Dictionary. 9th ed., 2009.

English, Leo James. English-Tagalog Dictionary.16th ed., National Bookstore, 1997.

Francisco, Juan R. Notes on Probable Tamil Words in Philippine Languages. U of the Philippines Main Library, 1965.

-.. "Sanskrit Loanwords in the Philippine Languages." Readings in Philippine Linguistics, edited by Andrew Gonzalez, Teodoro Llamzon, and Fe Otanes, Linguistic Society of the Philippines, 1973, pp. 678-736.

Francisco, Juan R. Indian Culture in the Philippines: Views and Reviews. U of Malaya, 1985. Gonda, Jan. Sanskrit in Indonesia. Nagpur, 1952.

Gonzalez, Andrew. "Contemporary Filipino (Tagalog) and Kapampangan: Two Philippine Languages in Contact." Current Issues in Philippine Linguistics and Anthropology: Parangal kay Lawrence A. Reid, edited by Hsiu-chuan Liao and Carl G. Rubino, 
Linguistic Society of the Philippines and Summer Institute of Linguistics, 2005, pp.

93-114.

Goulet, Rosalina Morales. "English, Spanish and Tagalog: A Study of Grammatical, Lexical and Cultural Interference." Philippine Journal of Linguistics, Special Monograph Issue, no. 1, July 1971.

Haspelmath, Martin and Uri Tadmor. World Loanword Database. Leipzig, 2009.

Haugen, Einar. "The analysis of linguistic borrowing." Language, vol. 26, no. 2, 1950, pp. 210-231.

Kelz, Heinrich. "The Phonology of Language Contact." Parangal cang Bro. Andrew, edited by Ma. Lourdes S. Bautista, T.A. Llamzon, and B.P. Sibayan, Linguistic Society of the Philippines, 2000, pp. 30-37.

Kern, Hendrik. "Sanskritsche Woorden in Het Tagala."Bijdragen tot de Taal,- Land-en Volkenkunde van Nederlandsch Indic vol. 4, no. 4, 1881, pp. 535-564.

Lopez, Cecilio. "Foreign Influences in Tagalog." Philippine Review, vol. 2, no. 2, April 1944, pp. 43-49.

Lopez, Cecilio. "The Spanish Overlay in Tagalog." Readings in Philippine Linguistics, edited by Andrew B. Gonzalez, Teodoro Llamzon, and Fe Otanes, Linguistic Society of the Philippines, 1973, pp. 737-766.

Mahootian, S. "Code Switching and Mixing." The Encyclopedia of Language and Linguistics, Elsevier, 2006, pp. 511- 527.

Makarenko, Vladimir. "South Indian Influence on Philippine Languages." Philippine Journal of Linguistics, vol. 23, no. 1-2, June-December 1992, pp. 65-79.

Manuel, E. Arsenio. Chinese Elements in the Tagalog Language. Filipiniana, 1948.

Monier-Williams M., ed. A Sanskrit-English Dictionary. [1st edition published by Oxford UP, 1899], reprint, Motilal Banarsidass, 1997.

Myers-Scotton, Carol. Language Contact: Bilingual Encounters and Grammatical Outcomes. Oxford, 2002.

Ortograpiyang Pambansa. 2013 ed., Komisyon sa Wikang Pambansa, 2013.

Panganiban, Jose V. Spanish Loanwords in the Tagalog Language. Manila Bureau of Printing, 1961.

The Philippine Star, www.philstar.com/archives. Accessed 18 Feb. 2014.

Potet, Jean-Paul G. Arabic and Persian Loanwords in Tagalog. Lulu, 2013.

-.. Tagalog Borrowings and Cognates. Lulu, 2016.

Rachkov, E. G. Noviy Tagalsko-Russkiy Slovar' [New Tagalog-Russian Dictionary], vol. I-II. Saint-Petersburg State U, 2012.

Rubino, Carl R. Tagalog-English, English-Tagalog Dictionary. Hippocrene, 2000.

Schachter, Paul and Fe T. Otanes. Tagalog Reference Grammar. U of California P, 1972.

Steinkrüger, Patrick O. "Hispanisation processes in the Philippines."Hispanisation: The impact of Spanish on the lexicon and grammar of the indigenous languages of Austronesia and the Americas, edited by Thomas Stolz, Dik Bakker and Rosa S. Palomo, Mouton de Gruyter, 2008, pp. 203-236.

Kritika Kultura 28 (2017): -054

(c) Ateneo de Manila University

<http://journals.ateneo.edu/ojs/kk/> 
Stolz, Thomas. "Survival in a niche: On gender-copy in Chamorro (and sundry languages)." Morphologies in Contact, edited by M. Vanhove, T. Stolz, and A. Urdze, Akademie Verlag, 2012, pp. 93-140.

Studenichnik, Yu. I. “Glagoly Taglish: mag- vs. -um-.” Pilipinas muna! The Philippines is a Priority, edited by M. V. Stanyukovich, Russian ed., Saint Petersburg UP, 2011, pp. 289-305.

Tagalog-English Dictionary. National Bookstore, 2002.

Thomason, Sarah G. Language Contact: An Introduction. Edinburgh UP, 2001.

Thompson, Roger M. Filipino English and Taglish: Language Switching from Multiple Perspectives. John Benjamins, 2003.

Wilkinson R.J. A Malay-English Dictionary (Romanized). Macmillan, 1959.

Wolff, John. "The character of borrowings from Spanish and English in the languages of the Philippines." Journal of Philippine Linguistics, vol. 4, no. 1, 1973, pp. 72-81.

--. "Malay Borrowings in Tagalog." Southeast Asian History and Historiography: Essays presented to D.G.E. Hall, edited by C.D. Cowan and O.W. Wolters. Cornell UP, 1976, pp. 345-367.

-.. "The influence of Spanish on Tagalog."Lo propio y lo ajeno en las lenguas austronésicas y ameríndias. Procesos interculturales en el contacto de lenguas indigenas con el español en el Pacífico e Hispanoaérica, edited by Klaus Zimmerman and Thomas Stolz, Vervuert, 2001, pp. 233-252.

Zorc, David. "The prehistory and origin of the Tagalog people." Language: A Doorway between Human Cultures (Volume in honour of Dr. Otto Chr. Dahl on his goth birthday), Novus Forlag, 1993, pp. 201-211.

Zorc, D. and R. San Miguel. Tagalog Slang Dictionary. De La Salle UP, 2000.

Zuraw, Kie. Floating Phonotactics: Infixation and Reduplication in Tagalog Loanwords. MA Thesis, UCLA, 1996, www.linguistics.ucla.edu/people/zuraw/dnldpprs/FlPhono.pdf. Accessed 10 Dec. 2016. 